\title{
VEIO DAS SOMBRAS
}

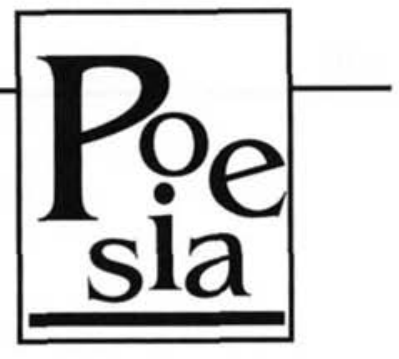

Veio das sombras,

Da memória de todos os tempos.

Do menino nascendo, veio.

Veio das novenas, das lajes, dos terços

$\mathrm{E}$ de sinos tangendo em monjolos e moinhos.

Do menino crescendo, veio.

Veio do orgulho, das árvores, das raízes

E de relógios sem ponteiros e máquinas Singer.

Do menino caminhando, veio.

Veio de estrelas já extintas e tão distantes

E de chuvas tão inúteis e de terras sem sementes.

Do menino falando, veio.

Veio do suor nas enxadas e das lágrimas nas peneiras

E da injustiça feita homem-Deus-colono.

Do menino observando, veio.

Veio de perfumes, leques, retratos

E de mulheres com camafeu e de cortinas de filé.

Do menino sonhando, veio.

Veio de balaústres, demandas, heranças, lustres

E do sangue feito canga ou coroa de espinhos.

Do menino sonhando, veio.

Veio de rastelos cantando canções estrangeiras

$\mathrm{E}$ de todos os sangues que não correm em mim.

Do menino sofrendo, veio.

Veio de tábuas largas, melindrosas, telha-vã

E do menino ouvindo os vissi darte e os vissi damore

\section{O AUTOR}

Jorge Andrade (Aluísio Jorge Andrade Franco) Nasceu em Barretos, Estado de São Paulo, em 21 de maio de 1922. Filho de fazendeiros, começou sua carreira teatral em 1951, estreando como escritor, com a peça O telescópio. Autor de A moratória, Pedreira das almas, Vereda da salvação, A escada, Os ossos do Barão, Senhora na boca do lixo, Rastro atrás, As confrarias e $\mathrm{O}$ sumidouro. Para a teledramaturgia fez Os ossos do Barão, O grito, Gaivotas, Dulcinéia, Os adolescentes, Ninho da serpente, Sabor de mel.

1. A poesia precede a primeira das peças, As confrarias, de $\mathbf{O}$ ciclo, conjunto de peças de Jorge Andrade. In: ANDRADE, Jorge. Marta, a árvore e o relógio. São Paulo: Perspectiva, 1970. 658p. 
Entre latido de cães, pés na enxurrada e mangas no chão.

Do menino humilhado, veio.

Veio de livros roubados e de pedras procuradas.

Veio dos momentos vividos e sonhados.

Veio das sombras,

Da memória de todos os tempos.

Do menino libertado, veio! 